BANCA D'ITALIA

E U R O S I S T E M A

Temi di discussione

(Working Papers)

Domestic and global determinants of inflation: evidence from expectile regression

by Fabio Busetti, Michele Gaivano and Davide Delle Monache

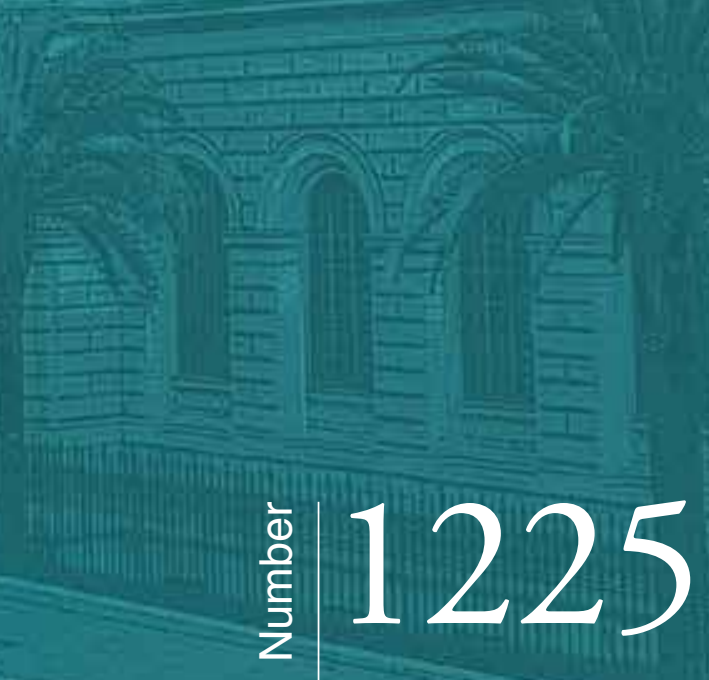





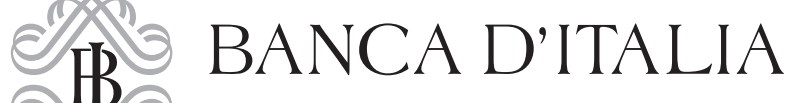

E U ROS I S T E MA

\section{Temi di discussione} (Working Papers)

Domestic and global determinants of inflation: evidence from expectile regression

by Fabio Busetti, Michele Caivano and Davide Delle Monache

Number 1225 - June 2019 
The papers published in the Temi di discussione series describe preliminary results and are made available to the public to encourage discussion and elicit comments.

The views expressed in the articles are those of the authors and do not involve the responsibility of the Bank.

Editorial Board: Federico Cingano, Marianna Riggi, Emanuele Ciani, Nicola Curci, Davide Delle Monache, Francesco Franceschi, Andrea Linarello, Juho Taneli Makinen, Luca Metelli, Valentina Michelangeli, Mario Pietrunti, Lucia Paola Maria Rizzica, Massimiliano Stacchini.

Editorial Assistants: Alessandra Giammarco, Roberto Marano.

ISSN 1594-7939 (print)

ISSN 2281-3950 (online)

Printed by the Printing and Publishing Division of the Bank of Italy 


\title{
DOMESTIC AND GLOBAL DETERMINANTS OF INFLATION: EVIDENCE FROM EXPECTILE REGRESSION
}

\author{
by Fabio Busetti ${ }^{*}$, Michele Caivano* and Davide Delle Monache*
}

\begin{abstract}
The paper investigates the role of domestic and global determinants of euro area core inflation. We analyse the entire conditional distribution of inflation by estimating a Phillips curve type relationship using an expectile regression approach, extended to capture time-varying effects. The main findings are as follows. First, both the domestic and foreign output gap are significant drivers of euro area core inflation, once external demand pressures are properly orthogonalized in a modified measure of domestic gap. However, the inflationary impact of the domestic component is relatively stronger. Second, the domestic output gap has a bigger influence in the right tail of the conditional distribution of inflation. Third, adding international price pressures in the regression weakens the link between inflation and the foreign output gap. Fourth, in a time- varying perspective, there is an increase in the response of inflation to the domestic gap in the last decade but only at the lower quantiles. Overall, the evidence on the so-called "globalization hypothesis" is mixed: while the pass-through to inflation of foreign prices and the exchange rate increased over time at all quantiles, the impact of global slack remained broadly stable, particularly in the central part of the distribution.
\end{abstract}

JEL Classification: C53, E17.

Keywords: asymmetric least squares, globalization, inflation quantiles, Phillips curve, time varying parameters.

\section{Contents}

1. Introduction

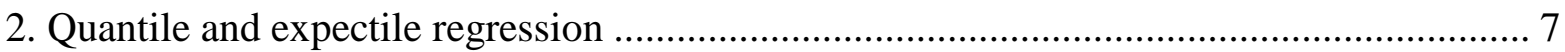

3. Disentangling domestic and global determinants of inflation: preliminary OLS evidence....... 9

3.1. Removing global demand in a measure of domestic output gap ............................... 10

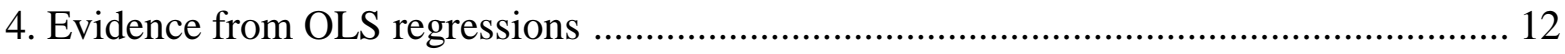

5. Using expectile regressions to assess the impact on the conditional distribution of inflation .... 14

5.1 Time-varying effects for conditional expectiles and the globalization hypothesis .... 15

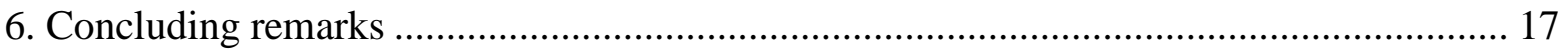

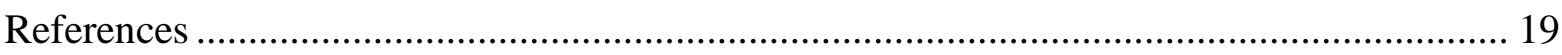

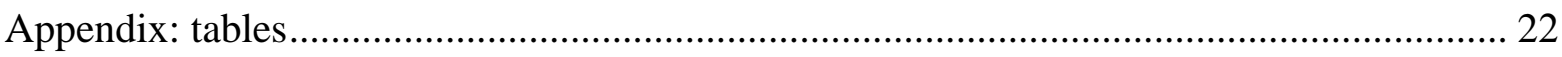

\footnotetext{
* Bank of Italy, Directorate General for Economics, Statistics and Research.
} 



\section{Introduction ${ }^{*}$}

Inflation rates tend to move together in advanced economies as a result of common trends in commodity prices and a certain degree of synchronization of business cycles and monetary policies. For example, Ciccarelli and Mojon (2010) found that a global factor accounts for nearly $70 \%$ of the variance of inflation in 22 OECD countries. ${ }^{1}$

Some authors have further argued that globalization has made inflation react relatively more to global economic conditions, with some additional impact on top of the standard channel of import prices. The reason is that increased trade integration may "have made markets much more contestable, eroding the pricing power of both labour and firms"; see, among else, Borio and Filardo (2007), Auer et al. (2017), Borio (2017, p. 4). Forbes (2018) provides considerable empirical evidence to support this claim and she illustrates the various channels through which globalization may affect firms pricing decision. Other empirical studies nevertheless find no or only negligible effects of global economic slack on domestic inflation. ${ }^{2}$

The Phillips curve is the standard framework to describe the relationship between inflation and demand pressures, labour market conditions and firms'pricing policies in a closed economy; in empirical investigations it is usually augmented to capture inflation expectations and the pass-through of import and commodity prices. In the 2000's several policymakers flashed a 'flattening' of the Phillips curve, i.e. a lower response of inflation to measures of economic slack. In contrast to the view on globalization, the flattening was mainly linked to the change of paradigm in monetary policy, switched to explicit inflation targeting, that has proved successful for stabilizing actual and expected inflation; see, among else, Roberts (2006), Williams (2006), Mishkin (2007), Gaiotti (2010). During the last decade, the possibility of changes in the sensitivity of inflation to economic slack has been related to nonlinearities and mismeasurements in output and unemployment gaps. ${ }^{3}$

This paper investigates the role of domestic and global determinants of euro area core inflation. The focus is on the entire conditional distribution of inflation. We estimate a Phillips curve type relationship through the method of expectile

\footnotetext{
${ }^{*}$ The view expressed here are those of the authors and do not necessarily reflect those of the Bank of Italy.

${ }^{1}$ Further evidence of a large global component of inflation is given in Monacelli and Sala (2009), Neely and Rapach (2011), Delle Monache, Petrella and Venditti (2016), Carriero, Corsello and Marcellino (2018). The weight of the global factor is lower when inflation is measured net of the energy and food components.

${ }^{2}$ See, among else, Ball (2006), Calza (2009), Milani (2010), Ihrig et al. (2010), Mikolajun and Lodge (2016), ECB (2017), Bereau et al. (2018). Bianchi and Civelli (2015) nd that global slack affects the dynamics of inflation in many countries, but its influence has not become stronger over time.

${ }^{3}$ See, for instance, Ball and Mazumder (2011), Riggi and Venditti (2015).
} 
regression (or asymmetric least squares), that is here extended in a novel way to capture time-varying effects. Expectiles describe the whole distribution of a stochastic variable and can be easily mapped into quantiles if wished so; see Newey and Powell (1987), Efron (1991). Hence expectile methods can be used also to estimate specific quantiles. Compared with quantiles, conditional expectiles are simpler to characterize, which facilitates the extension to a time-varying framework proposed here.

The main findings of our study are as follows. First, as expected, domestic and foreign output gaps tend to be highly correlated making it generally difficult to disentangle their effect on inflation. However we find that both of them are significant drivers of euro area core inflation, once external and domestic demand pressures are properly orthogonalized. The inflationary impact of the domestic component is however relatively stronger. The orthogonalization of domestic and foreign demand pressures has been achieved by simulating, through a VARX model, a counterfactual path for the euro area GDP based on a foreign demand variable net of its cyclical component. This model-based orthogonalization has not been considered in other works, in which empirical results might be obscured by collinearity of regressors. Second, domestic output gap has a stronger impact in the right tail of the conditional distribution of inflation. Third, adding international price pressures in the regression (imported prices and the exchange rate) weakens the link between inflation and foreign output gap. Fourth, in a time-varying perspective, there is an increase of the response of inflation to domestic gap in the latest decade but only at the lower quantiles. The pass-through to inflation of import prices and the exchange rate tends to become stronger over time at all quantiles. Finally, the underlying model-based measure of core inflation shows a tendency to fall in recent periods.

Other papers have analyzed the conditional distribution of inflation in a quantile regression framework, but without explicitly allowing for time-varying effects. Manzan and Zerom (2013) argue that macroeconomic indicators are useful for predicting the distribution of US inflation, while Wolters and Tillman (2015) find a decrease in persistence at all quantiles since the early Eighties. The distribution of euro area inflation is analyzed in Busetti, Caivano, Rodano (2015), Busetti (2017), Bereau, Faubert, Schmidt (2018) and Tagliabracci (2019) with findings that are broadly comparable to what presented here for the case of fixed coefficients.

In general, several studies have shown that the (augmented) Phillips curve is not stable over relatively long time spans; see e.g. IMF (2006), Stock and Watson (2009), Musso, Stracca, VanDijk (2009). Looking at the recent evidence on possible structural changes and time-varying parameters, our empirical results confirm the claim of Forbes (2018) of an increase of the role of global factors in the last decade in terms of the response to import prices and the exchange rate, but not with 
respect to foreign demand pressures; this latter result is in line with Bianchi and Civelli (2015). Then, if we restrict to the lower quantiles of the distribution, our results share some similarity with Riggi and Venditti (2015) where the possibility of an increased response of euro area inflation to cyclical conditions is investigated.

The paper proceeds as follows. Section 2 presents the methodological framework of expectile regression, that is here extended to allow for time-varying coefficients. Section 3 introduces a model-based measure of domestic output gap, net of foreign demand pressures. Preliminary OLS evidence on a Phillips curve relationship with domestic and global drivers is presented in section 4 . In section 5 the regression model is estimated for several conditional quantiles/expectiles of euro area core inflation and empirical evidence on time-variation of the regression coefficients is provided. Section 6 concludes.

\section{Quantile and expectile regression}

Let $q(\alpha)$ be the quantile of order $\alpha \in(0,1)$ of a random variable with a continuous distribution function $F($.$) , i.e. F(q(\alpha))=\alpha$. The empirical quantile from a sample of $n$ observations $y_{1}, y_{2}, \ldots, y_{n}$ can be computed by ordering them in ascending order or, equivalently, by minimizing

$$
S_{\alpha}=\sum_{t=1}^{n} \xi_{\alpha}\left(y_{t}-q\right)
$$

where $\xi_{\alpha}(e)=e(\alpha-I(e<0))$ is the so-called 'check function' and $I($.$) denotes$ the indicator function.

Expectiles are measures of location similar to quantiles, but they are determined by tail expectations rather than tail probabilities. For a random variable with a finite mean, the expectile of order $\omega \in(0,1)$, denoted as $\mu(\omega)$, is defined by the following equation ${ }^{4}$

$$
(1-\omega) \int_{-\infty}^{\mu(\omega)}(y-\mu(\omega)) d F(y)+\omega \int_{\mu(\omega)}^{\infty}(y-\mu(\omega)) d F(y)=0 .
$$

The sample expectile is obtained by minimizing

$$
L_{\omega}=\sum_{t=1}^{n} \rho_{\omega}\left(y_{t}-\mu\right)
$$

where $\rho_{\omega}(e)=e^{2}|\omega-I(e<0)|$; see Newey and Powell (1987), Efron (1991). This is also called 'asymmetric least squares' since the estimate minimizes the squared

\footnotetext{
${ }^{4}$ For quantiles the corresponding equation is given by $(1-\alpha) \int_{-\infty}^{q(\alpha)} d F(y)-\alpha \int_{q(\alpha)}^{\infty} d F(y)=0$.
} 
residuals giving them different weight according to whether they are positive or negative. Note that $\omega=0.5$ corresponds to Ordinary Least Squares and hence the estimate is the sample mean. Busetti and Harvey (2010) construct tests of stability of a distribution function based on partial sums of the first derivative of $\rho_{\omega}\left(y_{t}-\widehat{\mu}(\omega)\right)$, where $\widehat{\mu}(\omega)$ is the sample expectile; similar tests are obtained for quantiles. $^{5}$

Quantiles and expectiles can be easily mapped into each other. For a given quantile $q(\alpha)$ there is a corresponding expectile of order $\omega(\alpha)$ given by

$$
\omega(\alpha)=\frac{\alpha q(\alpha)+\int_{q(\alpha)}^{\infty} y d F(y)}{2 \int_{q(\alpha)}^{\infty} y d F(y)-(1-2 \alpha) q(\alpha)} .
$$

The formula is obtained by equating the definitions of $q(\alpha)$ and $\mu(\omega)$ and then solving for $\omega$; see also Yao and Tong (1996). As an example, for a Gaussian distribution $\mu(.25)=q(.33)$. In practice, given an estimate of an expectile the corresponding quantile order can be obtained by counting the numbers of observations below that value (Efron, 1991). ${ }^{6}$

Expectiles may depend on covariates. Assuming a linear relation with a vector of covariates $x, \mu(\omega \mid x)=\beta^{\prime} x$, the parameter $\beta$ can be estimated by expectile regression,

$$
\widehat{\beta}(\omega)=\arg \min \sum_{t=1}^{n} \rho_{\omega}\left(y_{t}-x_{t}^{\prime} \beta\right),
$$

which is the obvious extension of (1). This boils down to OLS when $\omega=0.5$. As shown in Newey and Powell (1987), $\widehat{\beta}(\omega)$ can be expressed as 'iterated weighted least square estimator', i.e. the solution of the equation

$$
\widehat{\beta}(\omega)=\left[\sum_{t=1}^{n} w_{t}(\widehat{\beta}(\omega)) x_{t} x_{t}^{\prime}\right]^{-1} \sum_{t=1}^{n} w_{t}(\widehat{\beta}(\omega)) x_{t} y_{t}
$$

where the weights are

$$
w_{t}(\widehat{\beta}(\omega))=\left|\omega-1\left(y_{t}-x_{t}^{\prime} \widehat{\beta}(\omega)<0\right)\right| .
$$

Newey and Powell (1987) show that, under regularity conditions, the asymmetric least square estimator (2) is asymptotically Gaussian. The estimator of the limiting variance can be easily computed.

\footnotetext{
${ }^{5}$ De Rossi and Harvey (2009) extend a standard unobserved component framework to track time variation in quantiles and expectiles.

${ }^{6}$ As showed in Taylor (2008), expectiles are also closely related to Expected Shortfall $(E S(\alpha))$, a risk measure defined as the average value in the left tail of the distribution where the tail is delimited by $q(\alpha), \alpha<0.5$. Let $\omega(\alpha)$ be the expectile order corresponding to the $\alpha$-quantile, then, for a random variable with zero mean, $E S(\alpha)=\mu(\omega(\alpha))\left(1+\frac{\alpha}{(1-2 \alpha) \omega(\alpha)}\right)$.
} 
The simple expression for the estimator (2) facilitates an extension to a timevarying parameter framework. Here we propose a modification of the Kernel estimation of Giraitis et al. (2014), which is itself a generalization of the rolling window estimator. The time-varying expectile regression coefficient is hence given by

$$
\widehat{\beta}_{t}(\omega)=\left[\sum_{s=1}^{n} K\left(\frac{t-s}{H}\right) w_{s}\left(\widehat{\beta}_{s}(\omega)\right) x_{s} x_{s}^{\prime}\right]^{-1} \sum_{s=1}^{n} K\left(\frac{t-s}{H}\right) w_{s}\left(\widehat{\beta}_{s}(\omega)\right) x_{s} y_{s}
$$

where $K(x) \geq 0$ is a usual kernel function, e.g. $K(x)=\frac{3}{4}\left(1-x^{2}\right) 1(|x| \leq 1)$ or $K(x)=(2 \pi)^{-0.5} \exp \left(-0.5 x^{2}\right)$, and $H$ is the bandwidth. Giraitis et al. (2014) derive the limiting properties of this type of estimator for a standard regression model with stochastic coefficients. A generalization of those asymptotic results to the case of expectile regression is beyond the scope of this paper.

\section{Disentangling domestic and global determinants of inflation: preliminary OLS evidence}

The output gap is generally measured through statistical filtering of the data, aimed at extracting the fluctuations (at business cycle frequencies) around an underlying trend. The so-called HP filter is a simple example. Filtering may be applied either to GDP or to each of its supply components (labour, capital and total factor productivity) assuming an aggregate production function for the economy. Although different filtering methods produce alternative results, the estimates typically share broadly similar characteristics and they are highly correlated. For example, the estimates of the euro area output gap produced by the IMF, OECD and European Commission are shown in the left-hand panel of Figure 1, together with the outcome of a standard HP filter. As it often happens, differences tend to be larger towards the end of the sample, when revisions due to new data are important.

Several authors have argued that global demand pressures may be an important driver of domestic inflation since trade integration "have made markets much more contestable, eroding the pricing power of both labour and firms"; see, among else, Borio and Filardo (2007), Auer et al. (2017), Forbes (2018). Borio and Filardo (2007) suggest to measure global economic slack by taking a weighted average of countries output gaps, where the weights reflect the commercial links with those countries (i.e. trade-weighted foreign output gap). The right-hand side panel of Figure 1 shows a proxy of foreign output gap for the euro area constructed precisely in that way, using the weights for the main trade partners with the euro 
area. The red line is constructed as a weighted average of the IMF estimates of countries annual output gap; the pink dotted line is similar except that each country output gaps is computed by a standard HP filter applied to quarterly GDP. By comparison, we also show two (equally weighted) measures of output gap for advanced economies, obtained by the IMF and OECD data respectively. Overall they are all broadly similar, as expected.

As business cycles and monetary policies show a certain degree of synchronization internationally, particularly among advanced economies, it is no surprise that the euro area output gap in the left panel of the figure shows a similar pattern to the proxy of global slack reported in the right panel. Hence, due to collinearity, it may be difficult to disentangle their effects in a regression model for inflation. As an alternative strategy one could think of constructing a proxy of domestic output gap that reflect business cycle developments net of the impact of foreign demand pressures. This would break most of the correlation between domestic and foreign output gap, making it easier to include both of them in a model for inflation. This is done in the next subsection using counterfactual simulations of a simple econometric model.
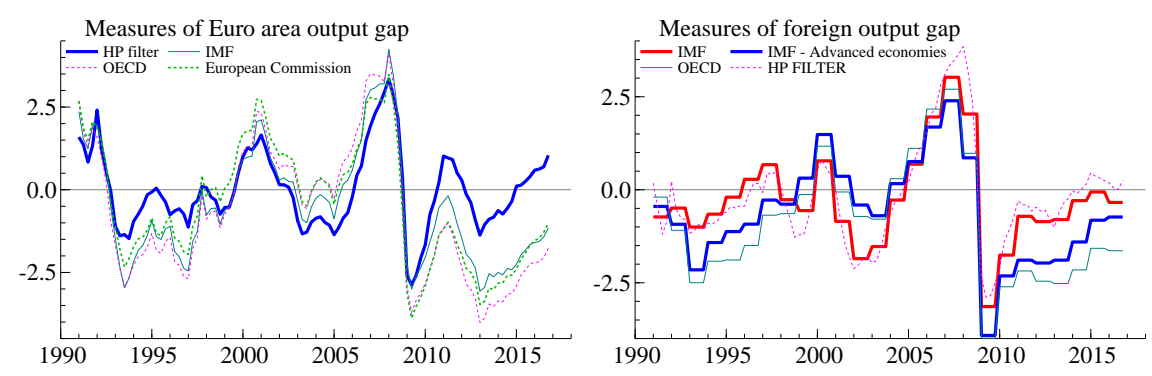

Figure 1: Output gap in the euro area and in the world economy

\subsection{Removing global demand in a measure of domestic out- put gap}

We start from a simple VARX model with 3 endogenous variables (real GDP, consumption deflator, long term interest rates), 2 lags and 3 exogenous variables (foreign demand, oil prices in euro, short term interest rates), estimated over the period 1980-2016; all variables, except for the interest rates, are in logs. Foreign demand is computed on the basis of real imports of goods and services of the main trading partners of the euro area. The data are taken from the Area Wide Model dataset, available online at https://eabcn.org/page/area-wide-model. In order to construct counterfactual simulations of euro area GDP net of foreign 
demand pressures, we are mostly interested in the dynamic responses of our VARX model with respect to a shock in foreign demand. These are shown in Figure 2 and compared with two benchmarks (that help validating our estimates): the ECB euro area wide model and the euro area aggregation of countries' results of the econometric models of the Eurosystem's national central banks; the figures are taken from Fagan and Morgan (2005, p.41). According to these results, a $1 \%$ increase of foreign demand rises the level of euro area GDP between 0.1 and 0.2 percentage points on average on a three-year horizon; the impact is somewhat more front-loaded in our simple VARX compared to macroeconometric models of the ECB and the national central banks.

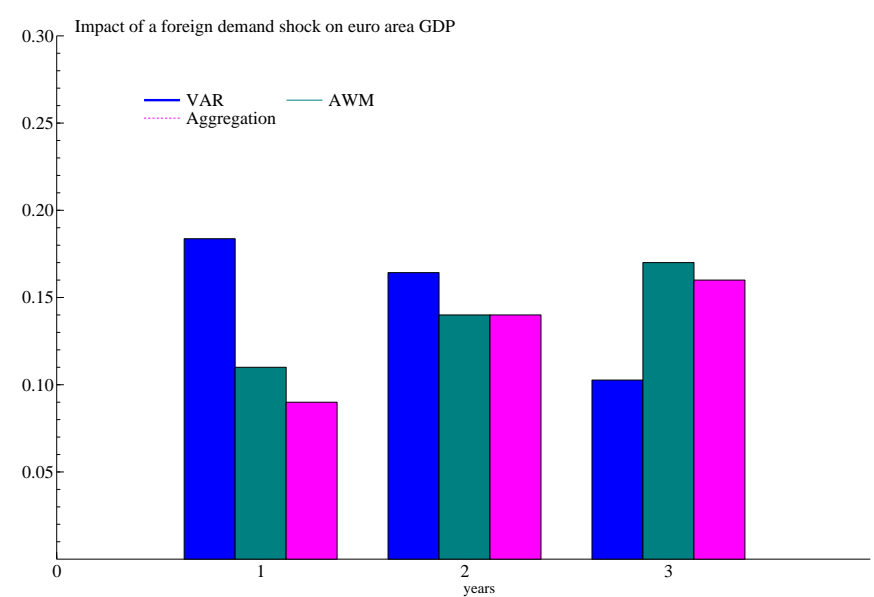

Figure 2: Elasticities of the euro area GDP to a permanent $1 \%$ increase in foreign demand

A measure of euro area domestic output gap, net of foreign demand pressures is computed as follows. First, a counterfactual path for the exogenous variable of foreign demand is assumed, imposing that it grows at a constant rate throughout the simulation period (the average growth rate over 1980-2016); hence, by assumption, global cyclical fluctuations are removed. ${ }^{7}$ Then the VARX model is simulated under this alternative assumption of foreign demand to generate a counterfactual path of euro area GDP that, by construction, will be net of the global demand pressures. A 'domestic output gap' measure for the euro area is finally obtained by applying the HP filter to the counterfactual GDP series.

\footnotetext{
${ }^{7}$ This is arguably a crude approximation of a counterfactual scenario since, for instance, it ignores implications for commodity prices and the possibility of changes in the underlying trend of global output. Nevertheless, since we are not interested in the path of euro area GDP per se but only in its deviation from a trend, our approximation is less crude than could seem at a first sight.
} 
The left-hand panel of Figure 3 shows the foreign output gap, the standard measure of euro area output gap (HP filter) and our proxy for the domestic component of the gap computed through the counterfactual simulation just described. While the standard euro area output gap (in red) and the foreign output gap (in black) look broadly similar, different patterns are clearly visible between the foreign gap and our measure of (counterfactual) domestic gap. For example, in 2009 the domestic component of output gap is not particularly negative, consistently with the evidence that the recession was mostly of imported nature; conversely, from 2011 to 2016, during the sovereign debt crisis and the following recovery the slack in the euro area appears to be mainly driven by its domestic component.

The scatter plot of the standard euro area output gap (red crosses) and the counterfactual measure of domestic demand pressures (blue squares) against the foreign gap is shown in the right-hand panel of Figure 3. The implied regression lines confirm a low correlation of the domestic and foreign gaps (R-square equal to 0.04), which supports the use of these two proxies as separate drivers in a model for inflation.
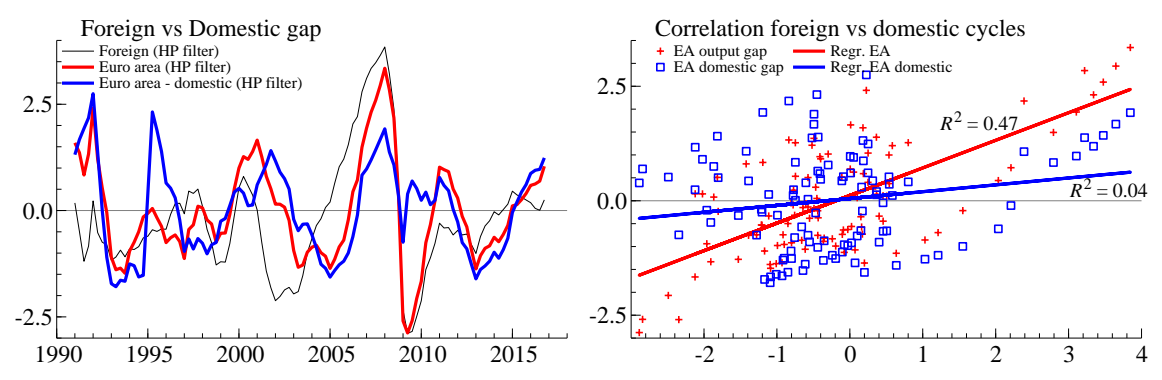

Figure 3: Domestic component of the euro area GDP

\section{Evidence from OLS regressions}

As a preliminary evidence, we estimate by OLS a standard Phillips curve type relationship for the euro area (with quarterly data over the period 1989-2016),

$$
\pi_{t}=\beta_{0}+\beta_{1} \pi_{t-1}+\beta_{2}^{\prime} x_{t-1}+\varepsilon_{t},
$$

where $\pi_{t}=100\left(p_{t} / p_{t-4}-1\right)$ is the year-on-year inflation rate which depends on its lagged values and on a set of covariates $x_{t-1}$, including (foreign and/or domestic) output gap and external price pressures (measured by the percentage change of either the import deflator or the effective exchange rate of the euro); $\beta=\left(\beta_{0}, \beta_{1}, \beta_{2}^{\prime}\right)^{\prime}$ is the vector of slope parameters and $\varepsilon_{t}$ is a stochastic disturbance. 
Inflation is defined in terms of the Harmonized Index of Consumer Prices net of the more volatile components (food and energy) in order to insulate from the often large fluctuations due to commodity prices. The data for inflation, GDP, import prices and nominal effective exchange rate are taken from the area wide model database, while the measures of domestic and foreign output gap are those described in the previous section.

Table 1 in the appendix shows the regression results for several specifications ${ }^{8}$, labelled (a) to (g); the coefficients highlighted in bold are statistically significant at least at the $5 \%$ level using HAC standard errors.

In all models the lagged dependent variable, domestic output gap and external price pressures are significant drivers of euro area core inflation, in line with the Phillips curve arguments and the empirical evidence of large degree of persistence in the inflation process.

Models (a) through (d) consider a standard measure of domestic gap, based on a HP filter of euro area GDP but the results would be similar for other cases. The slope coefficient is between 0.07 and 0.09 , meaning that a one percent rise of output gap yields an immediate increase of inflation of nearly 0.1 percent and then gradually keeps feeding prices through the autoregressive component. In these regressions foreign output gap (measured by the weighted average of gaps of euro area trading partners) is not significant. This could be partly due to its correlation with the standard measure of output gap (as showed in Figure 3) yielding an issue of collinearity among regressors.

If our model-based orthogonalized measure of output gap is used (which basically removes the impact of external demand pressures) then both components of domestic and foreign output gap contribute to explaining the dynamics of core inflation; cf. columns (e), (f), (g). Their coefficients basically sum up to the one attached to the standard measure of gap in (a)-(d). Note that adding the import deflator to the equation weakens the link between inflation and foreign gap, showing that some of external demand pressures are already accounted in foreign prices developments.

Overall this preliminary OLS evidence suggests that our strategy of orthogonalizing domestic and foreign demand pressures is successful for modelling the conditional mean of core inflation. In the next sections we look if both measures of output gaps remain significant in explaining the lower and upper quantiles of the distribution of inflation using the method of expectile regression. We then explore the presence of time-varying effects.

\footnotetext{
${ }^{8}$ The results are similar results if the covariates $x_{t}$ enter the regression without lag.
} 


\section{Using expectile regressions to assess the im- pact on the conditional distribution of infla- tion}

Expectile regressions allow to track the properties of the distribution of euro area inflation (e.g. in terms of dispersion, asymmetry and tail behavior) as a function of the state of the economy. Both demand and supply determinants of inflation are considered and they are allowed to have different impact in different regions of the distribution and over time. in particular, a Phillips curve relationship (4) is estimated using the method of expectile regression, as described in Section 2. The vector of regression parameters now depends on the expectile order $\omega$. We show results for $\omega=.05, .10, .25, .75, .90, .95$ and compute the corresponding quantiles orders; note that $\omega=.50$ boils down to the OLS regression showed previously.

Table 2 in the appendix reports the results for the simpler model where inflation depends only on its past values and on output gap, which is however disentangled into domestic and foreign components. Hence it generalizes regression (e) of Table 1 ; the constant term is not displayed.

A clear finding is that domestic demand pressures have stronger effects on the upper right tail of the distribution of core inflation; the slope coefficient is about three times larger and the statistical significance is also higher. The impact of foreign gap appears on the other hand rather similar across quantiles, although it is somewhat stronger in the lower part of the distribution. Note that the implicit quantile orders, reported in the last row of the Table, are not strikingly different from what implied by a Gaussian distribution, where e.g. $\omega=.05$ (.25) corresponds to $\alpha=.13(.33)$.

Overall, the upper side of the distribution of core inflation appears relatively more influenced by positive developments in the domestic economy than those at a global level, while the converse seems true for the left tail of the distribution. The results hence suggest that economic policies that stimulate the domestic economy may have a relatively smaller impact on inflation if global conditions remain weak.

Table 3 then displays results where a measure of foreign price pressure, either the import deflator or the nominal effective exchange rate, is added in the regression. As for the case of the conditional mean, it is found that the import deflator appears to partly capture also the impact of foreign gap, which becomes no longer statistical significant. Foreign gap remains however statistically significant if the exchange rate replaces the import deflator in the regression. A further interesting finding is that foreign price pressures have similar (and statistically significant) effects across all quantiles of core inflation. 


\subsection{Time-varying effects for conditional expectiles and the globalization hypothesis}

The time-varying expectile regression framework introduced in section 2 is used to investigate whether the relationship at different quantiles between core inflation and its main drivers has changed over time. In particular, we are interested in the so-called 'globalization hypothesis' which would show up in a stronger influence of foreign variables in driving the dynamics of domestic inflation.

The left panel of Figure 4 shows the time-varying coefficients of domestic output gap for expectile orders $\omega=0.10,0.50,0.90$ in an expectile regression model which contains both domestic and foreign variables, as in case (e) of Table 1. The coefficients of foreign output gap are instead displayed in the right panel of the figure.
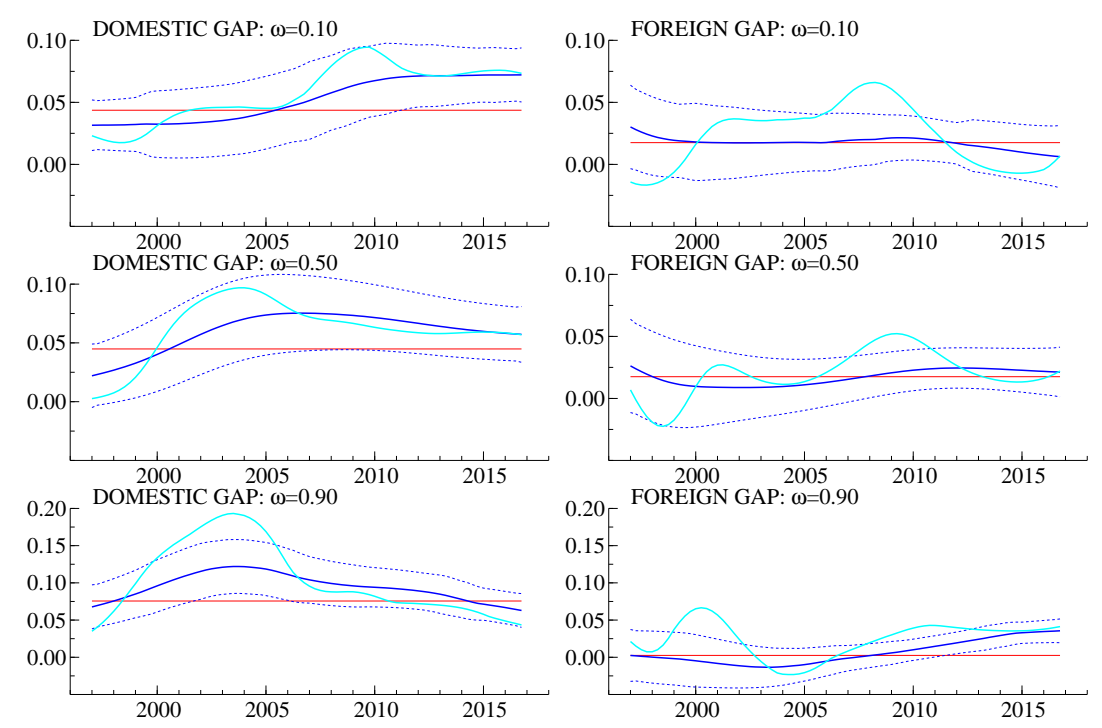

Figure 4: Coefficient estimates on the domestic and foreign gap

The time varying parameters are computed using formula (3) for two different values of the bandwidth parameter (that controls the degree of smoothing of the time-varying coefficients), with the dark (light) blue line indicating the case of more (less) smoothing; the first 8 years of observations are used to initialize the estimators. The values of the bandwidth parameter are chosen ad-hoc just to illustrate the sensitivity to the estimates to more local observations. For comparison, the fixed expectile regression coefficient is also showed in red (which for 
$\omega=0.5$ corresponds to the OLS coefficient). The confidence bands, displayed for the case of more smoothing, represent 2 times the time-varying standard deviation of the coefficient. ${ }^{9}$

Looking at the coefficients of domestic output gap the figure provides evidence of some increase in the slope of the Phillips curve in the latest decade but only for the lower quantiles; the response of foreign gap appears on the other hand more stable throughout time, with only some tendency to increase (from zero or slightly negative values) for $\omega=0.90$.

The inflation response to foreign prices is showed in Figure 5. The left panel of the graph contains the time varying coefficients of the import deflator for the expectile regression corresponding to model (e) of Table 1. The right panel considers instead model (f) of Table 1, where the import deflator is replaced by the nominal effective exchange rate.
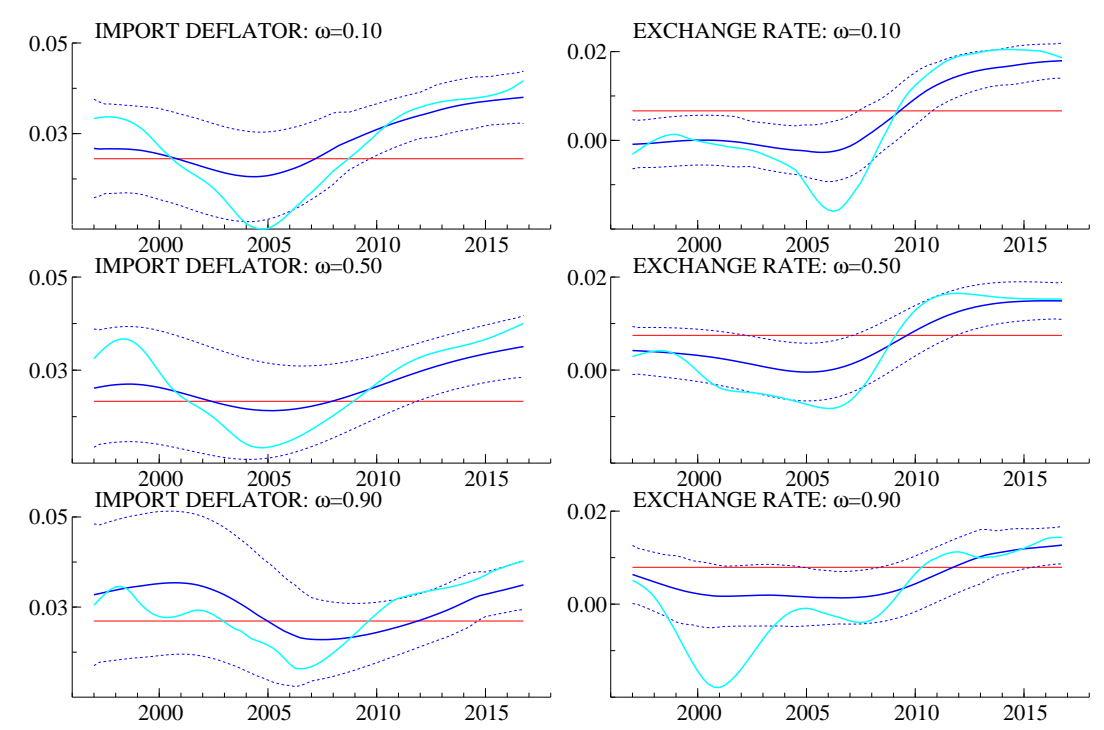

Figure 5: Coefficient estimates on the import deflator and the exchange rate

It is interesting to note that: (i) the coefficients are strikingly similar for all

${ }^{9}$ The variance matrix of the time-varying expectile regression coefficient, $\widehat{V}_{t}\left(\widehat{\beta}_{t}(\omega)\right)$, is computed following Giraitis et al. (2014). Using the notation of Section 2, $\widehat{V}_{t}\left(\widehat{\beta}_{t}(\omega)\right)=$ $\left.\left.\sum_{s=1}^{n} K_{t s} w_{t s}(\omega) x_{s} x_{s}^{\prime}\right)^{-1} \sum_{s=1}^{n} K_{t s}^{2} w_{t s}^{2}(\omega) u_{s}^{2} x_{s} x_{s}^{\prime}\right)\left(\sum_{s=1}^{n} K_{t s} w_{t s}(\omega) x_{s} x_{s}^{\prime}\right)^{-1}$, where $K_{t s}=$ $K\left(\frac{t-s}{H}\right), w_{t s}(\omega)=w_{s}\left(\widehat{\beta}_{t}(\omega)\right), u_{s}=y_{s}-x_{s}^{\prime} \widehat{\beta}_{t}(\omega)$. 
expectile orders $\omega=0.10,0.50,0.90$; (ii) the pass-through of foreign prices and exchange rate fluctuations to core inflation gets stronger in the last decade.

Taking the evidence of Figure 4 and 5 together, our analysis provides only partial support for the globalization hypothesis, since the contribution of foreign slack appears mostly stable over time.

Finally, Figure 6 shows the time-varying behavior of the long run centering parameter, i.e. $\beta_{0} /\left(1-\beta_{1}\right)$ in the formula (4), for $\omega=0.25,0.50,0.75$. Since the output gap and the import deflator regressors have been demeaned, the case of $\omega=0.50$ corresponds to the long-run mean of the inflation process, i.e. a measure of underlying inflation, which in the figure is plotted with the $2 \%$ threshold. It is interesting to see that underlying core inflation was close to $2 \%$ in the early 2000 's but it has then decreased to just below $1.5 \%$ in more recent periods. The dispersion around the long-run mean of core inflation has also become smaller in the last decade.

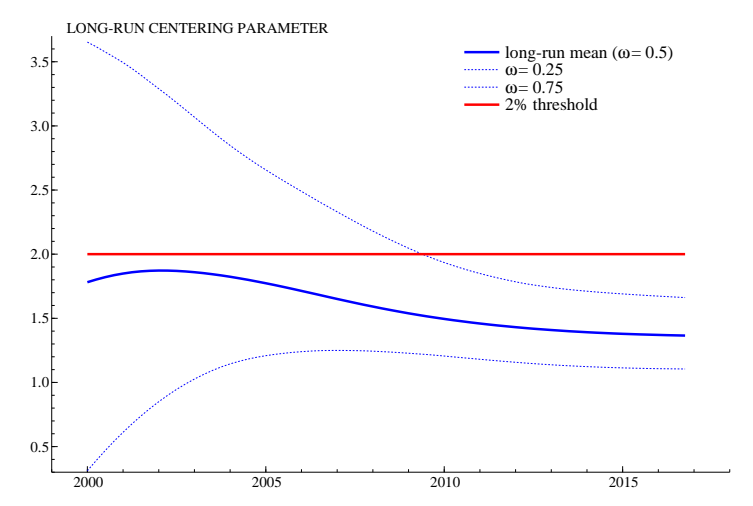

Figure 6: Long run centering parameter

\section{Concluding remarks}

The paper has analyzed the role of domestic and global drivers on the conditional distribution of euro area inflation through an expectile regression approach. Two methodological novelties have been introduced. First, expectile regression has been extended to capture the possibility of time-varying coefficients. Second, a modelbased measure of domestic slack of the euro area economy net of the fluctuations of the global business cycle has been proposed, which allows a better identification of the impact of foreign and domestic demand pressures on inflation. On the empirical side, it is found that both foreign and domestic output gap are significant drivers of the euro area inflation, with the effect of the domestic output gap being 
relatively stronger. The response of inflation to internal demand pressures is overall stronger in the upper quantiles of the distribution, although the sensitivity in the lower quantiles has increased in more recent years. In terms of the implications for the 'globalization hypothesis', our findings show that the pass-through of import prices and the exchange rate has become higher in most recent periods, while the impact of foreign demand pressures on inflation appears to be broadly stable over time, particularly in the central part of the distribution. 


\section{References}

[1] Auer, R., Borio, C., Filardo, A., 2017. The Globalization of Inflation: the Growing Importance of Global Value Chains. Bank for International Settlements Working Paper No. 602.

[2] Ball, L.M., 2006. Has globalization changed inflation? NBER Working Paper Series, 12687.

[3] Ball, L.M., Mazumder, S., 2011. Inflation Dynamics and the Great Recession. Brookings Papers on Economic Activity 42(1), 337-405.

[4] Béreau, S., Faubert, V., Schmidt, K., 2018. Explaining and Forecasting Euro Area Inflation: the Role of Domestic and Global Factors. Banque de France Working Paper 663.

[5] Bianchi, F., Civelli, A., 2015. Globalization and inflation: Evidence from a time-varying VAR. Review of Economic Dynamics 18(2), 406-433.

[6] Borio, C., Filardo, A., 2007. Globalisation and inflation: new cross-country evidence of the global determinants of domestic inflation. Bank of International Settlements Working Paper 227.

[7] Borio, C., 2017. Through the looking glass. OMFIF City Lecture, Bank of International Settlements.

[8] Busetti, F., 2017. Quantile aggregation of density forecasts. Oxford Bulletin of Economics and Statistics 79(4), 495-512.

[9] Busetti, F., Caivano, M., Rodano, L., 2015. On the conditional distribution of euro area inflation forecasts. Bank of Italy Working Papers, n. 1027.

[10] Busetti, F., Harvey, A.C., 2010. Tests of strict stationarity based on quantile indicators. Journal of Time Series Analysis, 31(6), 435-450.

[11] Calza, A., 2009. Globalization, domestic inflation and global output gaps: evidence from the Euro Area. International Finance 12 (3), 301-320.

[12] Carriero, A., Corsello, F., Marcellino, M., 2018. The global component of inflation volatility. Bank of Italy Working Papers, n. 1170.

[13] Ciccarelli, M., Mojon, B., 2010. Global inflation. Review of Economics and Statistics $92(3), 524-535$. 
[14] Delle Monache, D., Petrella, I., Venditti, F., 2016. Common Faith or Parting Ways? A Time Varying Parameters Factor Analysis of Euro-Area Inflation. Advances in Econometrics,in: Dynamic Factor Models, volume 35, 539-565, Emerald Publishing Ltd.

[15] De Rossi, G., Harvey, A.C., 2009. Quantiles, expectiles and splines. Journal of Econometrics 152(2), 179-185.

[16] Efron, B., 1991. Regression percentiles using asymmetric least squared error loss, Statistica Sinica, 93-125.

[17] European Central Bank, 2017. Domestic and global drivers of inflation in the euro area. ECB Economic Bulletin, 4/2017.

[18] Fagan, G., Morgan, J., 2005. Econometric Models of the Euro-area Central Banks. Edward Elgar Publishing.

[19] Forbes, K.J., 2018. Has globalization changed the inflation process. Paper prepared for 17th BIS Annual Research Conference held in Zurich on June 22.

[20] Gaiotti, E., 2010. Has Globalization Changed the Phillips Curve? Firm-Level Evidence on the Effect of Activity on Prices. International Journal of Central Banking 6 (1), 51-84.

[21] Giraitis, L., Kapetanios, G., Yates, T., 2014. Inference on stochastic timevarying coefficient models. Journal of Econometrics 179 (1), 46-65.

[22] International Monetary Fund, 2006. Globalization and Inflation. World Economic Outlook, april.

[23] Ihrig, J., Kamin, S.B., Lindner, D., Marquez, J., 2010. Some simple tests of the globalization and inflation hypothesis. International Finance 13 (3), $343-375$.

[24] Manzan, S., Zerom, D., 2013. Are macroeconomic variables useful for forecasting the distribution of U.S. inflation? International Journal of Forecasting 29 (3), 469-478.

[25] Mikolajun, I., Lodge, D., 2016. Advanced economy inflation: the role of global factors. Working Paper Series 1948, European Central Bank.

[26] Milani, F., 2010. Global slack and domestic inflation rates: A structural investigation for G-7 countries. Journal of Macroeconomics 32, 968-981. 
[27] Mishkin, F.S., 2007. Inflation Dynamics. International Finance 10 (3), 317334.

[28] Monacelli, T., Sala, L., 2009. The International Dimension of Inflation: Evidence from Disaggregated Consumer Price Data. Journal of Money, Credit and Banking 41(s1), 101-120.

[29] Musso, A., Stracca, L., van Dijk, D., 2009. Instability and Nonlinearity in the Euro-Area Phillips Curve. International Journal of Central Banking 5 (2), $181-212$.

[30] Neely, C., Rapach, D.E., 2011. International comovements in inflation rates and country characteristics. Journal of International Money and Finance 30 (7), 1471-1490.

[31] Newey, W.K., Powell, J.L., 1987. Asymmetric least squares estimation and testing. Econometrica 55 (4), 819-847.

[32] Riggi, M., Venditti, F., 2015. Failing to Forecast Low Inflation and Phillips Curve Instability: A Euro-Area Perspective. International Finance 18 (1), 47-68.

[33] Roberts, J.M., 2006. Monetary Policy and Inflation Dynamics. International Journal of Central Banking 2 (3), 193-230.

[34] Stock, J.H., Watson, M.W., 2009. Phillips Curve Inflation Forecasts, in: Understanding Inflation and the Implications for Monetary Policy, a Phillips Curve Retrospective. Federal Reserve Bank of Boston.

[35] Tagliabracci, A., 2019. The Vulnerability of Euro Area Inflation Forecasts, mimeo.

[36] Taylor, J.W., 2008. Estimating Value at Risk and Expected Shortfall using expectiles. Journal of Financial Econometrics, 231-252.

[37] Williams, J.C., 2006. Inflation persistence in an era of well-anchored inflation expectations. FRBSF Economic Letter.

[38] Wolters, M.H., Tillmann, P., 2015. The changing dynamics of US inflation persistence: a quantile regression approach. Studies in Nonlinear Dynamics \& Econometrics 19 (2), 161-182.

[39] Yao, Q., Tong, H., 1996. Asymmetric least squares regression estimation: a nonparametric approach. Journal of Nonparametric Statistics 6 (2-3), 273292. 


\section{A Tables}

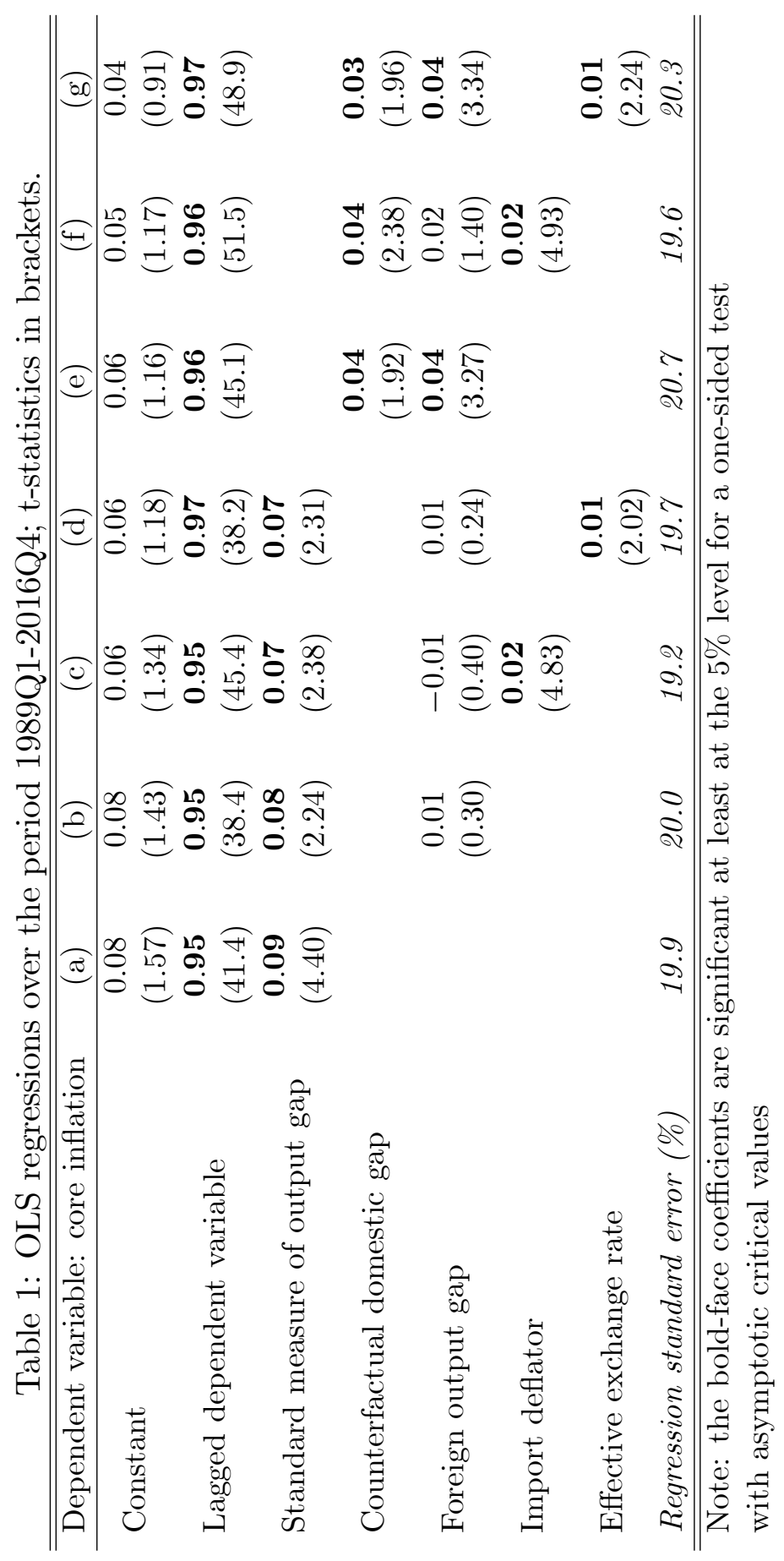




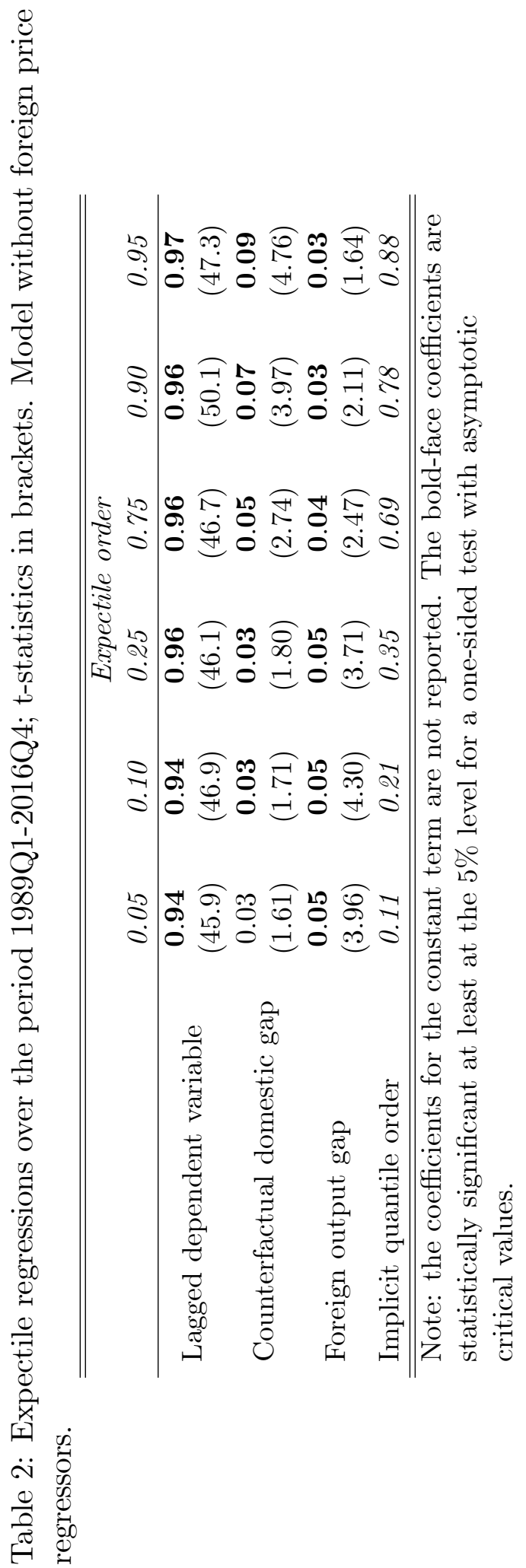




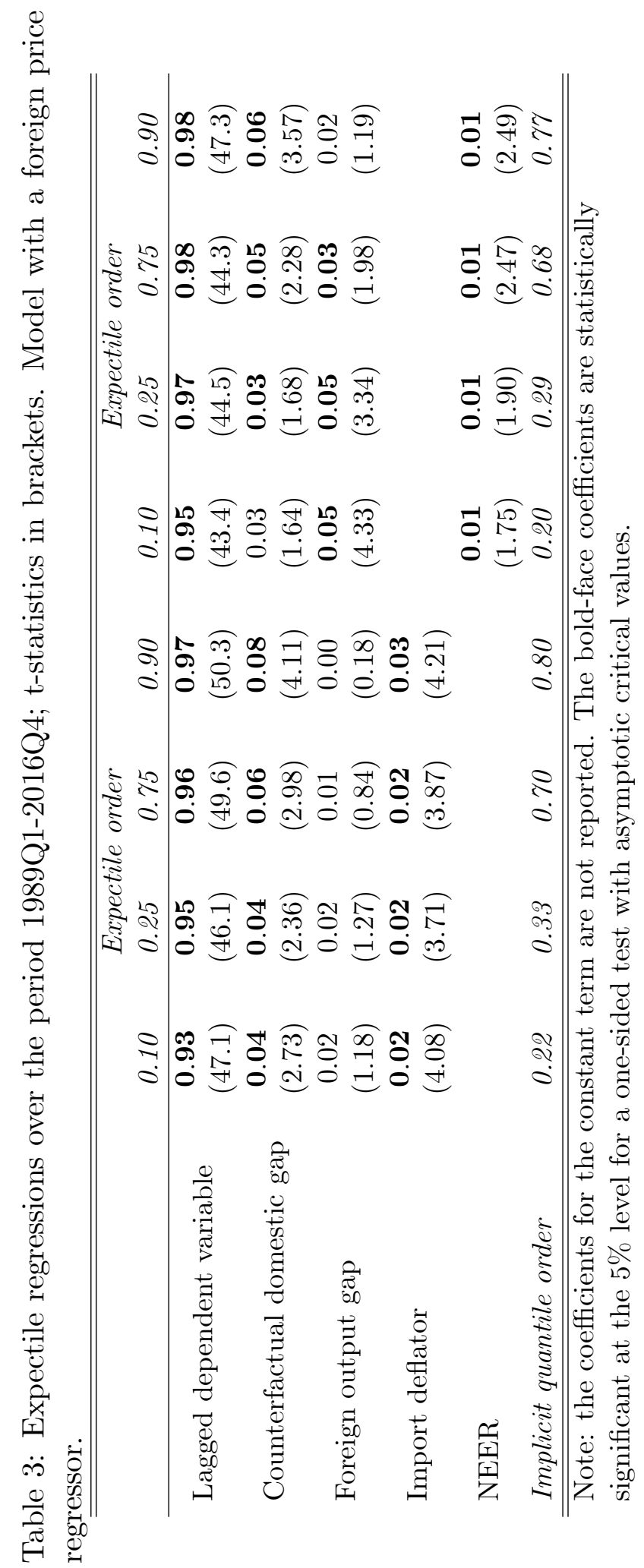




\section{RECENTLY PUBLISHED “TEMI” (*)}

N.1201 - Contagion in the CoCos market? A case study of two stress events, by Pierluigi Bologna, Arianna Miglietta and Anatoli Segura (November 2018).

N. 1202 - Is ECB monetary policy more powerful during expansions?, by Martina Cecioni (December 2018).

N. 1203 - Firms' inflation expectations and investment plans, by Adriana Grasso and Tiziano Ropele (December 2018).

N. 1204 - Recent trends in economic activity and TFP in Italy with a focus on embodied technical progress, by Alessandro Mistretta and Francesco Zollino (December 2018).

N.1205 - Benefits of Gradualism or Costs of Inaction? Monetary Policy in Times of Uncertainty, by Giuseppe Ferrero, Mario Pietrunti and Andrea Tiseno (February 2019).

N.1206 - Machine learning in the service of policy targeting: the case of public credit guarantees, by Monica Andini, Michela Boldrini, Emanuele Ciani, Guido de Blasio, Alessio D'Ignazio and Andrea Paladini (February 2019).

N. 1207 - Do the ECB's monetary policies benefit Emerging Market Economies? A GVAR analysis on the crisis and post-crisis period, by Andrea Colabella (February 2019).

N. 1208 - The Economic Effects of Big Events: Evidence from the Great Jubilee 2000 in Rome, by Raffaello Bronzini, Sauro Mocetti and Matteo Mongardini (February 2019).

N. 1209 - The added value of more accurate predictions for school rankings, by Fritz Schiltz, Paolo Sestito, Tommaso Agasisti and Kristof De Witte (February 2019).

N.1210 - Identification and estimation of triangular models with a binary treatment, by Santiago Pereda Fernández (March 2019).

N. 1211 - U.S. shale producers: a case of dynamic risk management, by Fabrizio Ferriani and Giovanni Veronese (March 2019).

N.1212 - Bank resolution and public backstop in an asymmetric banking union, by Anatoli Segura Velez (March 2019).

N. 1213 - A regression discontinuity design for categorical ordered running variables with an application to central bank purchases of corporate bonds, by Fan Li, Andrea Mercatanti, Taneli Mäkinen and Andrea Silvestrini (March 2019).

N.1214 - Anything new in town? The local effects of urban regeneration policies in Italy, by Giuseppe Albanese, Emanuele Ciani and Guido de Blasio (April 2019).

N. 1215 - Risk premium in the era of shale oil, by Fabrizio Ferriani, Filippo Natoli, Giovanni Veronese and Federica Zeni (April 2019).

N.1216 - Safety traps, liquidity and information-sensitive assets, by Michele Loberto (April 2019).

N. 1217 - Does trust among banks matter for bilateral trade? Evidence from shocks in the interbank market, by Silvia Del Prete and Stefano Federico (April 2019).

N.1218 - Monetary policy, firms' inflation expectations and prices: causal evidence from firm-level data, by Marco Bottone and Alfonso Rosolia (April 2019).

N.1219 - Inflation expectations and firms' decisions: new causal evidence, by Olivier Coibion, Yuriy Gorodnichenko and Tiziano Ropele (April 2019).

N. 1220 - Credit risk-taking and maturity mismatch: the role of the yield curve, by Giuseppe Ferrero, Andrea Nobili and Gabriele Sene (April 2019).

(*) Requests for copies should be sent to:

Banca d'Italia - Servizio Studi di struttura economica e finanziaria - Divisione Biblioteca e Archivio storico - Via Nazionale, 91 - 00184 Rome - (fax 003906 47922059). They are available on the Internet www.bancaditalia.it. 
Aaberge, R., F. Bourguignon, A. Brandolini, F. Ferreira, J. Gornick, J. Hills, M. Jäntti, S. Jenkins, J. Micklewright, E. Marlier, B. Nolan, T. Piketty, W. Radermacher, T. Smeeding, N. Stern, J. Stiglitz, H. Sutherland, Tony Atkinson and his legacy, Review of Income and Wealth, v. 63, 3, pp. 411-444, WP 1138 (September 2017).

AcCetturo A., M. Bugamelli and A. LAmorgese, Law enforcement and political participation: Italy 1861-65, Journal of Economic Behavior \& Organization, v. 140, pp. 224-245, WP 1124 (July 2017).

AdAmopoulou A. and G.M. TANZI, Academic dropout and the great recession, Journal of Human Capital, V. 11, 1, pp. 35-71, WP 970 (October 2014).

Albertazzi U., M. BotTero and G. SENE, Information externalities in the credit market and the spell of credit rationing, Journal of Financial Intermediation, v. 30, pp. 61-70, WP 980 (November 2014).

AlESSANDRI P. and H. MUMTAZ, Financial indicators and density forecasts for US output and inflation, Review of Economic Dynamics, v. 24, pp. 66-78, WP 977 (November 2014).

BARbieri G., C. Rossetti and P. SESTITO, Teacher motivation and student learning, Politica economica/Journal of Economic Policy, v. 33, 1, pp.59-72, WP 761 (June 2010).

Bentivogli C. and M. LitTERIO, Foreign ownership and performance: evidence from a panel of Italian firms, International Journal of the Economics of Business, v. 24, 3, pp. 251-273, WP 1085 (October 2016).

BRONZINI R. and A. D'IGNAZIO, Bank internationalisation and firm exports: evidence from matched firmbank data, Review of International Economics, v. 25, 3, pp. 476-499 WP 1055 (March 2016).

BRUChE M. and A. SEgurA, Debt maturity and the liquidity of secondary debt markets, Journal of Financial Economics, v. 124, 3, pp. 599-613, WP 1049 (January 2016).

Burlon L., Public expenditure distribution, voting, and growth, Journal of Public Economic Theory,, v. 19, 4, pp. 789-810, WP 961 (April 2014).

Burlon L., A. Gerali, A. Notarpietro and M. PisAni, Macroeconomic effectiveness of non-standard monetary policy and early exit. a model-based evaluation, International Finance, v. 20, 2, pp.155173, WP 1074 (July 2016).

BusEtTi F., Quantile aggregation of density forecasts, Oxford Bulletin of Economics and Statistics, v. 79, 4, pp. 495-512, WP 979 (November 2014).

CESARONI T. and S. IEZZI, The predictive content of business survey indicators: evidence from SIGE, Journal of Business Cycle Research, v.13, 1, pp 75-104, WP 1031 (October 2015).

CONTI P., D. MARELLA and A. NERI, Statistical matching and uncertainty analysis in combining household income and expenditure data, Statistical Methods \& Applications, v. 26, 3, pp 485-505, WP 1018 (July 2015).

D’AMURI F., Monitoring and disincentives in containing paid sick leave, Labour Economics, v. 49, pp. 7483, WP 787 (January 2011).

D'AMURI F. and J. MARCUCCI, The predictive power of google searches in forecasting unemployment, International Journal of Forecasting, v. 33, 4, pp. 801-816, WP 891 (November 2012).

DE BLASIO G. and S. POY, The impact of local minimum wages on employment: evidence from Italy in the 1950s, Journal of Regional Science, v. 57, 1, pp. 48-74, WP 953 (March 2014).

Del Giovane P., A. NoBiLi and F. M. SignORETTI, Assessing the sources of credit supply tightening: was the sovereign debt crisis different from Lehman?, International Journal of Central Banking, v. 13, 2, pp. 197-234, WP 942 (November 2013).

Del Prete S., M. PAGNini, P. Rossi and V. VACCA, Lending organization and credit supply during the 2008-2009 crisis, Economic Notes, v. 46, 2, pp. 207-236, WP 1108 (April 2017).

Delle Monache D. and I. Petrella, Adaptive models and heavy tails with an application to inflation forecasting, International Journal of Forecasting, v. 33, 2, pp. 482-501, WP 1052 (March 2016).

FEDERICO S. and E. TOSTI, Exporters and importers of services: firm-level evidence on Italy, The World Economy, v. 40, 10, pp. 2078-2096, WP 877 (September 2012).

Giacomelli S. and C. MENON, Does weak contract enforcement affect firm size? Evidence from the neighbour's court, Journal of Economic Geography, v. 17, 6, pp. 1251-1282, WP 898 (January 2013).

Loberto M. and C. Perricone, Does trend inflation make a difference?, Economic Modelling, v. 61, pp. 351-375, WP 1033 (October 2015). 
MANCINI A.L., C. MonfARdini and S. PASQUA, Is a good example the best sermon? Children's imitation of parental reading, Review of Economics of the Household, v. 15, 3, pp 965-993, D No. 958 (April 2014).

MEEKS R., B. NELSON and P. AlessANDRI, Shadow banks and macroeconomic instability, Journal of Money, Credit and Banking, v. 49, 7, pp. 1483-1516, WP 939 (November 2013).

MiCUCCI G. and P. Rossi, Debt restructuring and the role of banks' organizational structure and lending technologies, Journal of Financial Services Research, v. 51, 3, pp 339-361, WP 763 (June 2010).

Mocetti S., M. PAGNini and E. SETTE, Information technology and banking organization, Journal of Journal of Financial Services Research, v. 51, pp. 313-338, WP 752 (March 2010).

MocetTi S. and E. ViVIANO, Looking behind mortgage delinquencies, Journal of Banking \& Finance, v. 75, pp. 53-63, WP 999 (January 2015).

NoBili A. and F. Zollino, A structural model for the housing and credit market in Italy, Journal of Housing Economics, v. 36, pp. 73-87, WP 887 (October 2012).

PALAZzO F., Search costs and the severity of adverse selection, Research in Economics, v. 71, 1, pp. 171197, WP 1073 (July 2016).

Patacchini E. and E. Rainone, Social ties and the demand for financial services, Journal of Financial Services Research, v. 52, 1-2, pp 35-88, WP 1115 (June 2017).

PATACCHINI E., E. RAINONE and Y. ZENOU, Heterogeneous peer effects in education, Journal of Economic Behavior \& Organization, v. 134, pp. 190-227, WP 1048 (January 2016).

SBrana G., A. Silvestrini and F. VenditTI, Short-term inflation forecasting: the M.E.T.A. approach, International Journal of Forecasting, v. 33, 4, pp. 1065-1081, WP 1016 (June 2015).

SEgurA A. and J. SuAREZ, How excessive is banks' maturity transformation?, Review of Financial Studies, v. 30, 10, pp. 3538-3580, WP 1065 (April 2016).

VACCA V., An unexpected crisis? Looking at pricing effectiveness of heterogeneous banks, Economic Notes, v. 46, 2, pp. 171-206, WP 814 (July 2011).

Vergara CAFFAReli F., One-way flow networks with decreasing returns to linking, Dynamic Games and Applications, v. 7, 2, pp. 323-345, WP 734 (November 2009).

ZAGHINI A., A Tale of fragmentation: corporate funding in the euro-area bond market, International Review of Financial Analysis, v. 49, pp. 59-68, WP 1104 (February 2017).

Accetturo A., v. Di Giacinto, G. Micucci and M. Pagnini, Geography, productivity and trade: does selection explain why some locations are more productive than others?, Journal of Regional Science, v. 58, 5, pp. 949-979, WP 910 (April 2013).

AdAmopoulou A. and E. KAYA, Young adults living with their parents and the influence of peers, Oxford Bulletin of Economics and Statistics,v. 80, pp. 689-713, WP 1038 (November 2015).

ANDini M., E. Ciani, G. DE Blasio, A. D'Ignazio and V. Silvestrini, Targeting with machine learning: an application to a tax rebate program in Italy, Journal of Economic Behavior \& Organization, v. 156, pp. 86-102, WP 1158 (December 2017).

BARONE G., G. DE BLASIO and S. MOCETTI, The real effects of credit crunch in the great recession: evidence from Italian provinces, Regional Science and Urban Economics, v. 70, pp. 352-59, WP 1057 (March 2016).

Belotti F. and G. IlARDI Consistent inference in fixed-effects stochastic frontier models, Journal of Econometrics, v. 202, 2, pp. 161-177, WP 1147 (October 2017).

Berton F., S. Mocetti, A. Presbitero and M. Richiardi, Banks, firms, and jobs, Review of Financial Studies, v.31, 6, pp. 2113-2156, WP 1097 (February 2017).

Bofondi M., L. CARPInElli and E. SETTE, Credit supply during a sovereign debt crisis, Journal of the European Economic Association, v.16, 3, pp. 696-729, WP 909 (April 2013).

BokAn N., A. Gerali, S. Gomes, P. JACQUINOT and M. PISANI, EAGLE-FLI: a macroeconomic model of banking and financial interdependence in the euro area, Economic Modelling, v. 69, C, pp. 249280, WP 1064 (April 2016). 
BRILli Y. and M. TONELlo, Does increasing compulsory education reduce or displace adolescent crime? New evidence from administrative and victimization data, CESifo Economic Studies, v. 64, 1, pp. 15-4, WP 1008 (April 2015).

BUONO I. and S. FORMAI The heterogeneous response of domestic sales and exports to bank credit shocks, Journal of International Economics, v. 113, pp. 55-73, WP 1066 (March 2018).

Burlon L., A. GERAli, A. NotARPIETRO and M. PisAnI, Non-standard monetary policy, asset prices and macroprudential policy in a monetary union, Journal of International Money and Finance, v. 88, pp. 25-53, WP 1089 (October 2016).

CARTA F. and M. DE PHLIPPIS, You've Come a long way, baby. Husbands' commuting time and family labour supply, Regional Science and Urban Economics, v. 69, pp. 25-37, WP 1003 (March 2015).

CARTA F. and L. RIzZICA, Early kindergarten, maternal labor supply and children's outcomes: evidence from Italy, Journal of Public Economics, v. 158, pp. 79-102, WP 1030 (October 2015).

Casiraghi M., E. Gaiotti, L. Rodano and A. Secchi, A "Reverse Robin Hood”? The distributional implications of non-standard monetary policy for Italian households, Journal of International Money and Finance, v. 85, pp. 215-235, WP 1077 (July 2016).

CECChetti S., F. NATOLI and L. SigAlotTI, Tail co-movement in inflation expectations as an indicator of anchoring, International Journal of Central Banking, v. 14, 1, pp. 35-71, WP 1025 (July 2015).

CIANI E. and C. DEIANA, No Free lunch, buddy: housing transfers and informal care later in life, Review of Economics of the Household, v.16, 4, pp. 971-1001, WP 1117 (June 2017).

Cipriani M., A. Guarino, G. Guazzarotti, F. TAgliati and S. Fisher, Informational contagion in the laboratory, Review of Finance, v. 22, 3, pp. 877-904, WP 1063 (April 2016).

De Blasio G, S. De Mitri, S. D’Ignazio, P. Finaldi Russo and L. Stoppani, Public guarantees to SME borrowing. A RDD evaluation, Journal of Banking \& Finance, v. 96, pp. 73-86, WP 1111 (April 2017).

Gerali A., A. LocARno, A. NotArPIETRO and M. PISANI, The sovereign crisis and Italy's potential output, Journal of Policy Modeling, v. 40, 2, pp. 418-433, WP 1010 (June 2015).

LIBERATI D., An estimated DSGE model with search and matching frictions in the credit market, International Journal of Monetary Economics and Finance (IJMEF), v. 11, 6, pp. 567-617, WP 986 (November 2014).

Linarello A., Direct and indirect effects of trade liberalization: evidence from Chile, Journal of Development Economics, v. 134, pp. 160-175, WP 994 (December 2014).

NuCCI F. and M. RIGgI, Labor force participation, wage rigidities, and inflation, Journal of Macroeconomics, v. 55, 3 pp. 274-292, WP 1054 (March 2016).

RIGON M. and F. ZANETTI, Optimal monetary policy and fiscal policy interaction in a non_ricardian economy, International Journal of Central Banking, v. 14 3, pp. 389-436, WP 1155 (December 2017).

SEGURA A., Why did sponsor banks rescue their SIVs?, Review of Finance, v. 22, 2, pp. 661-697, WP 1100 (February 2017).

ARnAudo D., G. MiCUCCI, M. RIGON and P. Rossi, Should I stay or should I go? Firms' mobility across banks in the aftermath of the financial crisis, Italian Economic Journal / Rivista italiana degli economisti, v. 5, 1, pp. 17-37, WP 1086 (October 2016).

CIANI E., F. DAVID and G. DE BLASIO, Local responses to labor demand shocks: a re-assessment of the case of Italy, Regional Science and Urban Economics, v. 75, pp. 1-21, WP 1112 (April 2017).

CIANI E. and P. FISHER, Dif-in-dif estimators of multiplicative treatment effects, Journal of Econometric Methods, v. 8. 1, pp. 1-10, WP 985 (November 2014).

Chiades P., L. Greco, V. Mengotto, L. Moretti and P. Valbonesi, Fiscal consolidation by intergovernmental transfers cuts? The unpleasant effect on expenditure arrears, Economic Modelling, v. 77, pp. 266-275, WP 985 (July 2016). 
Giordano C., M. MARINUCCI and A. SiLveSTRINI, The macro determinants of firms' and households' investment: evidence from Italy, Economic Modelling, v. 78, pp. 118-133, WP 1167 (March 2018).

MONTEFORTE L. and V. RAPONI, Short-term forecasts of economic activity: are fortnightly factors useful?, Journal of Forecasting, v. 38, 3, pp. 207-221, WP 1177 (June 2018).

RigGi M., Capital destruction, jobless recoveries, and the discipline device role of unemployment, Macroeconomic Dynamics, v. 23, 2, pp. 590-624, WP 871 (July 2012).

\section{FORTHCOMING}

Albanese G., G. DE Blasio and P. Sestito, Trust, risk and time preferences: evidence from survey data, International Review of Economics, WP 911 (April 2013).

Aprigliano V., G. ARDIZZI and L. MONTEFORTE, Using the payment system data to forecast the economic activity, International Journal of Central Banking, WP 1098 (February 2017).

ARDUINI T., E. PATACCHINI and E. RAINONE, Treatment effects with heterogeneous externalities, Journal of Business \& Economic Statistics, WP 974 (October 2014).

BElotti F. and G. ILARDI, Consistent inference in fixed-effects stochastic frontier models, Journal of Econometrics, WP 1147 (October 2017).

BusetTi F. and M. CAIVANO, Low frequency drivers of the real interest rate: empirical evidence for advanced economies, International Finance, WP 1132 (September 2017).

Cappelletti G., G. Guazzarotti and P. Tommasino, Tax deferral and mutual fund inflows: evidence from a quasi-natural experiment, Fiscal Studies, WP 938 (November 2013).

CIANI E. and G. DE BLASIO, European structural funds during the crisis: evidence from Southern Italy, IZA Journal of Labor Policy, WP 1029 (October 2015).

COletta M., R. De Bonis and S. PIERMATteI, Household debt in OECD countries: the role of supply-side and demand-side factors, Social Indicators Research, WP 989 (November 2014).

CORSELlO F. and V. NISPI LANDI, Labor market and financial shocks: a time-varying analysis, Journal of Money, Credit and Banking, WP 1179 (June 2018).

Cova P., P. PAGANO and M. PISANI, Domestic and international macroeconomic effects of the Eurosystem Expanded Asset Purchase Programme, IMF Economic Review, WP 1036 (October 2015).

D’AMURI F., Monitoring and disincentives in containing paid sick leave, Labour Economics, WP 787 (January 2011).

D'Ignazio A. and C. MENOn, The causal effect of credit Guarantees for SMEs: evidence from Italy, Scandinavian Journal of Economics, WP 900 (February 2013).

ERCOLANi V. and J. VAlle E AzEVEDO, How can the government spending multiplier be small at the zero lower bound?, Macroeconomic Dynamics, WP 1174 (April 2018).

FEDERICO S. and E. TOSTI, Exporters and importers of services: firm-level evidence on Italy, The World Economy, WP 877 (September 2012).

GERAli A. and S. NeRI, Natural rates across the Atlantic, Journal of Macroeconomics, WP 1140 (September 2017).

Giacomelli S. and C. Menon, Does weak contract enforcement affect firm size? Evidence from the neighbour's court, Journal of Economic Geography, WP 898 (January 2013).

NAtoli F. and L. SigalotTI, Tail co-movement in inflation expectations as an indicator of anchoring, International Journal of Central Banking, WP 1025 (July 2015).

RAINONE E., The network nature of otc interest rates, Journal of Financial Markets, WP 1022 (July 2015).

RIZZICA L., Raising aspirations and higher education. evidence from the UK's widening participation policy, Journal of Labor Economics, WP 1188 (September 2018).

SEGURA A., Why did sponsor banks rescue their SIVs?, Review of Finance, WP 1100 (February 2017). 